\title{
Specificity of larval settlement of the Caribbean Orange Icing Sponge, Mycale laevis
}

\author{
Tse-Lynn Loh and Joseph R. Pawlik ${ }^{\mathrm{a}}$ \\ Department of Biology and Marine Biology and Center for Marine Science, \\ University of North Carolina Wilmington, Wilmington, North Carolina 28409, USA
}

\begin{abstract}
The Caribbean sponge Mycale laevis is often found growing in close proximity to living scleractinian corals. This commonly observed sponge-coral association has been considered a mutualism, with the coral providing substratum for the sponge, and the sponge protecting the coral skeleton from boring organisms. We examined the specificity of sponge recruitment to live corals, expecting a positive and specific settlement response if a mutualism exists. Benthic surveys conducted off Key Largo, Florida, and Bocas del Toro, Panama, revealed that individuals of $M$. laevis grew on substrata that included dead coral and other species of sponges. Selectivity analysis indicated that at three of the four survey sites, $M$. laevis was not randomly distributed, but associated with live corals more frequently than expected from proportional coral cover. However, settlement assays demonstrated that larvae of $M$. laevis did not preferentially respond to the presence of live coral. We have previously demonstrated that adults of $M$. laevis are chemically undefended and readily eaten by spongivorous fishes unless protected by adjacent substrata such as live corals. In overfished areas, where spongivore density is low, the sponge is not selectively distributed near corals. Initial results of settlement experiments with different substrata suggested that larvae of $M$. laevis responded positively to the presence of the chemically defended sponge Amphimedon compressa, perhaps indicating an associational defense. Further experiments revealed that larvae were reacting to artificially high concentrations of exudates from cut surfaces of $\mathrm{Am}$. compressa; settlement was not enhanced in response to healed pieces of Am. compressa. In addition, the larvae of $M$. laevis did not selectively respond to live coral or to chemically defended heterospecifics. These results indicate that the commonly observed proximity of $M$. laevis to live corals is not driven by larval settlement behavior, but instead by post-settlement mortality due to predation.
\end{abstract}

Additional key words: Porifera, symbiosis, recruitment, metamorphosis, chemical cues

Larval settlement behavior and post-settlement survivorship both greatly influence the demographics of sessile benthic marine organisms on coral reefs (Hughes 1984; McMurray et al. 2010). It may be evolutionarily advantageous for invertebrate larvae to be selective, responding to chemical or physical settlement cues that indicate an optimal environment (Pawlik 1992). In some cases, settlement cues are well understood; for example, larvae of some tube-building polychaetes respond to bacterial metabolites in biofilms (Harder et al. 2002), or free fatty acids present in the sand tubes of adult conspecifics (Pawlik \& Faulkner 1986; Pawlik 1988, 1992). Scleractinian corals have been the subject of considerable research,

\footnotetext{
${ }^{a}$ Author for correspondence.

E-mail: pawlikj@uncw.edu
}

with crustose coralline algae (Morse et al. 1994; Heyward \& Negri 1999; Ritson-Williams et al. 2009) and bacterial biofilms (Webster et al. 2004) identified as potential sources of larval settlement cues.

Relatively little is known about the settlement preferences of sponge larvae. Like scleractinian corals, sponges can broadcast gametes that are fertilized externally (Mariani et al. 2001; Ritson-Williams et al. 2004), or they can brood larvae before release (Lindquist \& Hay 1996; Collin et al. 2010). There is some debate as to whether sponge larvae respond strongly to cues from settlement substrata. As sponges lack a nervous system and well-developed sensory receptors, they were initially regarded as non-specific in terms of larval settlement, exhibiting no particular substratum preferences (Bergquist \& Sinclair 1968; Bergquist 1978). More recently, 
sponge larvae have been demonstrated to respond to chemical or textural cues, especially those from natural reef substrata. For example, the presence of coral rubble and coralline algae enhanced settlement of larvae of Reneira sp. in comparison with other substrata (Jackson et al. 2002), and larvae of Coscinoderma matthewsi (LENDENFELD 1886) attached and metamorphosed earlier in the presence of coral rubble and biofilmed surfaces (Abdul Wahab et al. 2011).

In this study, we considered possible factors that could affect sponge settlement choices. The orange icing sponge, Mycale laevis (CARTER 1882), is one of the ten most common sponges on Caribbean reefs (Pawlik et al. 1995), and is notable for its common proximity to scleractinian corals (Hill 1998). Sessile coral reef inhabitants frequently compete for space on the reef; however, the association between $M$. laevis and corals has been hypothesized to be a mutualism, in which the sponge gains substratum for growth (the underside of coral colonies), and the coral gains protection from bio-eroding organisms because the sponge covers susceptible coral skeleton (Goreau \& Hartman 1966). Because members of $M$. laevis grow on substrata other than coral skeleton adjacent to live coral, this potential mutualism is not obligate (Goreau \& Hartman 1966; Loh \& Pawlik 2009). Nonetheless, as a facultative mutualist, it would be expected that sponge larvae exhibit enhanced settlement and metamorphosis in response to the presence of live scleractinian corals. Hostspecificity has been demonstrated in many species of sessile invertebrates, such as sponge-inhabiting zoanthids (Crocker \& Reiswig 1981) and coral-boring bivalves (Mokady et al. 1991), with larvae hypothesized to respond to specific cues from their preferred hosts before settling. A similar response has been reported for larvae of the sponge Haliclona caerulea (Hechtel 1965) in response to its facultative algal host Jania adherens LAmouroux 1812, with $>90 \%$ of sponge larvae settling on algal fronds in choice experiments (Avila \& Carballo 2006).

Alternatively, the observed association between $M$. laevis and scleractinian corals could be driven by predation on sponges. Predation, particularly by spongivorous fishes, strongly regulates sponge populations on Caribbean reefs (Pawlik 1998; Pawlik et al. 2008). From field and laboratory assays, it is known that adults of $M$. laevis are chemically undefended and readily consumed by spongivorous fishes (Pawlik et al. 1995; Loh \& Pawlik 2009). By growing in the interstices and on the undersides of scleractinian coral colonies, the sponges take advantage of the physical protection offered by the hard and structurally complex coral skeletons to avoid predation. At least in areas with high spongivore densities, members of $M$. laevis clearly benefit from associating with corals, although reciprocal benefits for corals are unknown. In severely overfished areas, where sponge-eating fishes are scarce, $M$. laevis is released from predation pressure, and the association with corals is less evident, with the sponge growing over and on top of coral colonies, often smothering live coral polyps (Loh \& Pawlik 2009).

If associating with live corals increases the fitness of members of $M$. laevis, it would be beneficial for the larvae of $M$. laevis to preferentially settle on corals, and we would expect that adults of $M$. laevis would grow more frequently in proximity to live corals than on other reef substrata. To test these predictions, we performed benthic surveys on reefs off Key Largo, Florida, and Bocas del Toro, Panama, as well as larval settlement assays in the laboratory. Because general information on sponge reproduction is scarce, we also describe larval release and other reproductive characteristics of M. laevis.

\section{Methods}

\section{Benthic surveys}

Reef surveys were conducted at Conch Reef $\left(24^{\circ} 56.996^{\prime} \mathrm{N}, 80^{\circ} 27.223^{\prime} \mathrm{W}\right)$ and North Dry Rocks $\left(25^{\circ} 07.850^{\prime} \mathrm{N}, 80^{\circ} 17.521^{\prime} \mathrm{W}\right)$ in Key Largo, Florida, and Punta Caracol $\left(9^{\circ} 22.638^{\prime} \mathrm{N}, 82^{\circ} 18.152^{\prime} \mathrm{W}\right)$ and Adriana's Reef $\left(9^{\circ} 14.517^{\prime} \mathrm{N}, 82^{\circ} 10.415^{\prime} \mathrm{W}\right)$ in Bocas del Toro, Panama, to determine the relative abundance of possible sponge settlement substrata. Sites at Key Largo are protected from fishing and managed within the Florida Keys National Marine Sanctuary, while sites at Bocas del Toro are regarded as severely overfished (Loh \& Pawlik 2009). Five $20-\mathrm{m}$ transect lines were laid out in a single row along a constant depth at each survey site, and benthic community cover was recorded using the Global Coral Reef Monitoring Network Line Intercept Transect (LIT) methodology (English et al. 1997), in which the "length" of each benthic entity encountered under the transect tape was recorded. The total "length" for that organism summed up $>100 \mathrm{~m}$ was then used as a proxy for benthic cover. Surveys were conducted at depths of 13, 8, 6, and $5 \mathrm{~m}$ at Conch Reef, North Dry Rocks, Punta Caracol and Adriana's Reef, respectively. Sites at Key Largo were surveyed over November to December 2007, and sites at Bocas del Toro were surveyed in August 2007. 
To establish if adults of Mycale laevis are more commonly found on live scleractinian corals than on other substrata, 50 individuals of $M$. laevis were surveyed at each of the four reef sites listed above. Sponges were haphazardly selected along the same depths used for the benthic LIT, and the primary substratum was recorded for each individual. Sponges that were monitored were spaced $\geq 3 \mathrm{~m}$ apart on the reef, and the survey swim continued until 50 individuals were encountered. Based on the initial observations of substrata on which individuals of $M$. laevis grew, the following substrata were chosen for selectivity analysis: live scleractinian coral, dead coral (this category included coral pavement), gorgonians, other sponge species, and rubble (defined as loose pieces of dead coral smaller than $15 \mathrm{~cm}$ in length).

Chesson's $\alpha$ was calculated for each prospective substratum to test for selective distribution in the settlement of M. laevis (Chesson 1978). For each substratum $i, \alpha_{i}$ is defined as:

$$
\alpha_{i}=\left(r_{i} p_{i}^{-1}\right) / \sum_{j=1}^{k}\left(r_{j} p_{j}^{-1}\right)
$$

where $r$ is the proportion of the substratum type on which M. laevis was observed, $\mathrm{p}$ is the proportional availability of the substratum on the reef, and $\mathrm{k}$ is the number of substratum types. If $M$. laevis were found exclusively on one particular substratum, $\alpha$ for that substratum would be 1 ; if $M$. laevis were never found on a substratum, $\alpha$ would be 0 ; for a random distribution, $\alpha$ would be 0.2 .

\section{Larval settlement assays}

Adults of $M$. laevis brood non-tufted parenchymella larvae (Maldonado 2006) in chambers within the sponge mesohyl. Brooded embryos have been observed in sponge samples collected from Belize in August (Hajdu \& Rützler 1998), and larvae were present in sponges at Bocas del Toro in the months of July to September from 2007 to 2011 (T.-L. Loh, unpubl. data). Larvae of $M$. laevis were collected using larval traps deployed over sponges in the field at Casa Blanca reef flat $\left(9^{\circ} 21.461^{\prime} \mathrm{N}, 82^{\circ} 16.273^{\prime} \mathrm{W}\right)$ at depths of 1-4 m off Bocas del Toro, Panama, during the summer months of 2009-2011. For each field season, larval traps were placed over 22-29 individual sponges, with larval trap design based on methods in Lindquist (1996) and Henkel (2008). To construct larval traps, two holes were cut into the opposite sides of $200 \mathrm{~mL}$ Nalgene ${ }^{\odot}$ bottles; holes were then covered with $50 \mu \mathrm{m}$ plankton mesh. Bottles fit over the pointed end of a $50 \mathrm{~mL}$ plastic centrifuge tube with the tip cut off. The other opening of the centrifuge tube was attached to a nylon stocking mesh that was stretched over the oscules of the sponge. Mycale laevis is present in two color morphs at Bocas del Toro, white and orange (Loh et al. 2012); larvae were only collected from the orange morph. Traps were deployed in the late morning, and collected $24 \mathrm{~h}$ later. Larvae were brought back to the laboratory at the Smithsonian Tropical Research Institute (STRI) Bocas field station, and used in settlement assays the same afternoon they were collected.

All larval experiments were no-choice assays, in which swimming larvae of $M$. laevis were exposed to a single piece of reef substratum in a clean petri dish and scored for metamorphosis and attachment. Metamorphosis was defined as the stage when larvae stopped swimming, rounded up, and lost their external ciliated layer (Bergquist \& Green 1977), described in this article as the "ball" stage. For the first series of assays, August-September 2009, the experimental substrata were live pieces of the scleractinian coral Agaricia tenuifolia DANA 1846, dead pieces of Ag. tenuifolia with biofilm, dead pieces of $A g$. tenuifolia that had been scrubbed and dried, and freshly cut, live pieces of the reef sponge Amphimedon compressa Duchassaing \& MichelotTi 1864. Experimental substrata were trimmed to $\sim 1.5 \times 1.5 \times 0.3 \mathrm{~cm}^{3}$ pieces for use in the assays, and filtered seawater with no substratum was the control. Members of Ag. tenuifolia and Am. compressa are commonly found on the reefs at Bocas del Toro, and adults of M. laevis have been observed growing in proximity with members of both species (T.-L. Loh, unpubl. data).

Each experimental substratum was placed in a $10 \times 10 \times 1.5 \mathrm{~cm}^{3}$ square petri dish with $60 \mathrm{~mL}$ of filtered seawater and ten actively swimming sponge larvae. Three replicate assays were conducted for each treatment. Petri dishes were covered and placed in a darkened space. After 12 and $24 \mathrm{~h}$, the status of each larva was recorded as (1) attached (including attached and metamorphosed), (2) swimming, (3) not moving, or (4) metamorphosed but unattached. To maintain water quality, $30 \mathrm{~mL}$ of filtered seawater was replaced in each petri dish at $12 \mathrm{~h}$.

Results from the larval settlement assays with reef substrata indicated that the larvae of $M$. laevis responded positively to the presence of the sponge Am. compressa. Because the latter sponge is chemically defended from fish predators, we examined the possibility that proximity to Am. compressa might provide an associational defense for $M$. laevis. Heterospecific sponge mutualisms in which a palatable sponge benefits from growing in association with a chemically defended sponge have been demonstrated 
previously (Engel \& Pawlik 2000; Wilcox et al. 2002), and members of $M$. laevis have been observed to grow in close proximity to other species of sponges. To test for responses to heterospecifics, larvae of $M$. laevis were exposed to pieces of other sponge species in assays performed in July 2010. Sponges used as substrata in these assays were the chemically defended Am. compressa and Aplysina cauliformis (CARTER 1882), and the chemically undefended Iotrochota birotulata (HIGGIN 1877) and M. laevis. Dead pieces of the coral $\mathrm{Ag}$. tenuifolia were used as alternative substrata, and filtered seawater with no substratum was the control. Three replicate assays were conducted for each treatment. Sponge pieces were cut into $\sim 1.5 \times 1.5 \times 0.3 \mathrm{~cm}^{3}$ pieces, but for this round of experiments, pieces were allowed to heal in flow-through aquaria for $\geq 24 \mathrm{~h}$ before use. As before, ten larvae of $M$. laevis were introduced to substrata in petri dishes containing $60 \mathrm{~mL}$ of filtered seawater, and the number of attached larvae was counted every $6 \mathrm{~h}$ for $24 \mathrm{~h}$. For larval assays with reef substrata and sponge pieces, proportional larval attachment was arc-sine transformed and compared across treatments using repeated-measures ANOVA in SPSS v19 (IBM Armonk, NY, USA).

Differences in the responses of sponge larvae to pieces of Am. compressa that were freshly cut versus those allowed to heal resulted in follow-up assays to test the effects of aqueous exudates of Am. compressa on the metamorphosis and attachment of the larvae of M. laevis. Assays were conducted in August 2011. Volumetric displacement was used to measure $100 \mathrm{~mL}$ of freshly collected Am. compressa, which was then squeezed to render $61 \mathrm{~mL}$ of sponge juice. The $1 \times$ concentration of sponge juice in assays was defined to be the amount that would have been squeezed from a piece of Am. compressa measuring $1.5 \times 1.5 \times 0.3 \mathrm{~cm}^{3}$ in $60 \mathrm{~mL}$ of seawater, the size of the pieces used in the first round of larval settlement assays with reef substrata, which is equivalent to $6.85 \times 10^{-3} \mathrm{~mL}$ sponge juice $/ \mathrm{mL}$ seawater. Settlement response was monitored for larvae exposed to juice concentrations of $1 \times, 1 / 10 \times, 1 / 100 \times$ and $1 / 1000 \times$ (with three replicates at each concentration). Using the same protocol, a second set of assays exposed larvae to $2 \times$ concentrations of sponge juice. The various concentrations of sponge juice were achieved using serial dilutions in filtered seawater. For each replicate, five larvae were exposed to $10 \mathrm{~mL}$ of sponge juice at a specified concentration in a single well of a six-well cell culture plate. Metamorphosis and attachment of the sponge larvae were then monitored every $6 \mathrm{~h}$ over $72 \mathrm{~h}$. Larvae exposed to $2 \times$ sponge juice were monitored for $48 \mathrm{~h}$. After metamorphosis, in which larvae stopped swimming and rounded up to a "ball" stage, individuals were also monitored for further development to the "flattened" stage (Bergquist \& Green 1977). For M. laevis, the flattened stage was characterized by a flattening of the "ball" form, an increase in body size and the development of a ring of spicules around the juvenile sponge body. Dead larvae were only observed in assays with sponge juice, and were distinguished from non-moving living larvae by the change in body color from pale green to yellow, which was usually accompanied by a loss in the integrity of the outer surface of the larva (apparent using a dissecting microscope). Comparisons of the numbers of larvae in each settlement category across sponge juice concentrations were carried out using KruskalWallis analysis for non-parametric data in SPSS v19.

\section{Larval release and morphology}

Adult sponges were maintained in a laboratory aquarium to determine the timing of larval release. Seven individuals of $M$. laevis totaling $1140 \mathrm{~mL}$ in volume were collected from Punta Caracol, Bocas del Toro, in August 2011 from depths of 1-5 m and placed in an aquarium measuring $97 \times 97 \times 50 \mathrm{~cm}^{3}$ at the STRI Bocas facility. These individuals were collected intact, with no to minimal tissue damage, as they had been growing on sand in shallow reef areas at Bocas del Toro. These were then transferred carefully to the aquarium without exposure to air, and monitored for signs of stress (e.g., closed oscules, discoloration). The tank outflow $\left(\sim 12 \mathrm{~L} \mathrm{~min}^{-1}\right)$ was directed through a $300-\mu \mathrm{m}$ mesh to capture larvae released from the sponges. The number of larvae captured was checked every $4 \mathrm{~h}$ (with an $8 \mathrm{~h}$ gap from 22:00 to 06:00 hours) over $4 \mathrm{~d}$. An additional 12 individuals of $M$. laevis were dissected to observe the positions and sizes of the larval chambers within the sponge choanosome. The distances from the outer surface and the maximum diameters of five larval chambers were measured and averaged for each sponge individual, and overall mean distance and diameter was then calculated over 12 individuals. The dimensions of 20 larvae were measured under the dissecting microscope.

\section{Results}

\section{Distribution of adults of Mycale laevis}

About half of the individuals of Mycale laevis encountered at all sites were associated with live scleractinian coral (Table 1), regardless of whether survey sites were protected from fishing, or over- 
fished. On the reefs of Key Largo and at Punta Caracol, M. laevis was also likely to be found on dead coral (35-40\%). No members of $M$. laevis surveyed grew on dead coral at Adriana's Reef, but 34\% were observed to grow on other sponges (Table 1). Chesson's $\alpha$ indicated that $M$. laevis was selectively distributed on live scleractinian corals on the protected reefs at Key Largo, with $\alpha \geq 0.70$, which corresponds with high proportional distribution of $M$. laevis on corals relative to actual coral cover on those reefs. The distribution of M. laevis was more neutrally selective toward corals at Punta Caracol, an overfished site, with $\alpha=0.44$. Spongivorous fish density at Adriana's Reef is extremely low, but the sponge-eating seastar, Oreaster reticulatus (LinNAEus 1758), is abundant on this reef (Loh \& Pawlik 2009). Similar to results from both reefs in Key Largo with high spongivore densities, $M$. laevis was selectively distributed on live coral at Adriana's Reef, with $\alpha=0.70$. In terms of distribution, no strong associations were observed between members of $M$. laevis and the other substrata surveyed (Table 1).

\section{Larval settlement on reef substrata}

The behavior of larvae of $M$. laevis in settlement assay dishes was observed with a dissecting microscope and generally followed this sequence: (1) swimming slowed as a larva approached a solid surface; (2) the larva attached to the substratum at its anterior pole; (3) the larva metamorphosed to the "ball" stage; and finally, (4) the "ball" stage juvenile developed to the "flattened" stage, as described in the Methods. In some cases, larvae metamorphosed in the water column without first attaching to substrata; these juveniles were still subsequently able to attach and develop further.

In the first series of settlement assays with reef substrata, larvae of $M$. laevis started attaching in all treatments by $12 \mathrm{~h}$. By $24 \mathrm{~h}$, most of the larvae in the petri dishes with dead coral fragments or with the heterospecific sponge Am. compressa had attached (Fig. 1A). Proportional attachment differed significantly among substrata as the main effect (repeated-measures ANOVA, $\mathrm{p}<0.001$ ), no interaction between exposure time and substratum type was observed $(\mathrm{p}=0.483)$, and attachment increased over time in all treatments $(\mathrm{p}=0.005)$. From the Student Newman-Keuls (SNK) post hoc analysis, the group with the highest proportional attachment at $24 \mathrm{~h}$ comprised the treatments with dead coral and Am. compressa, with $86.7 \pm 3.3 \%$ (SE) and $90.0 \pm 5.8 \%$ of the larvae attached, respectively, followed by the control with filtered seawater, in which proportional attachment was $60.0 \pm 10.0 \%$. The groups with the lowest proportional attachment comprised treatments in which larvae were exposed to live scleractinian coral and scrubbed dead coral, with $33.3 \pm 3.3 \%$ and $36.7 \pm 12.0 \%$ of the larvae attached by $24 \mathrm{~h}$, respectively. In the treatment with

Table 1. Proportion of available settlement substrata ( $\mathrm{p}$ [Reef benthos]), proportion of substrata on which Mycale laevis was growing ( $\mathrm{p}[M$. laevis $]$ ), and Chesson's $\alpha$ for substratum preference of $M$. laevis for reefs off Key Largo, Florida, and Bocas del Toro, Panama. An $\alpha$ of 1 indicates exclusive selectivity, 0.2 indicates neutral selectivity, and 0 indicates negative selectivity of $M$. laevis for growth on that particular substratum.

\begin{tabular}{|c|c|c|c|c|c|c|}
\hline \multirow[b]{3}{*}{ Substratum } & \multicolumn{6}{|c|}{ Key Largo, Florida } \\
\hline & \multicolumn{3}{|c|}{ Conch Reef } & \multicolumn{3}{|c|}{ North Dry Rocks } \\
\hline & $\mathrm{p}$ [Reef benthos] & $\mathrm{p}[$ M. laevis $]$ & $\alpha$ & $\mathrm{p}$ [Reef benthos] & $\mathrm{p}[$ M. laevis $]$ & $\alpha$ \\
\hline Dead coral & 0.51 & 0.40 & 0.16 & 0.39 & 0.36 & 0.11 \\
\hline Live coral & 0.14 & 0.54 & 0.78 & 0.08 & 0.44 & 0.70 \\
\hline Rubble & 0.04 & 0 & 0 & 0.10 & 0.12 & 0.15 \\
\hline Gorgonian & 0.11 & 0 & 0 & 0.13 & 0.02 & 0.02 \\
\hline \multirow[t]{3}{*}{ Live sponge } & 0.20 & 0.06 & 0.06 & 0.31 & 0.06 & 0.02 \\
\hline & \multicolumn{6}{|c|}{ Bocas del Toro, Panama } \\
\hline & \multicolumn{3}{|c|}{ Punta Caracol } & \multicolumn{3}{|c|}{ Adriana's Reef } \\
\hline Dead coral & 0.30 & 0.35 & 0.34 & 0.07 & 0 & 0 \\
\hline Live coral & 0.34 & 0.52 & 0.44 & 0.08 & 0.58 & 0.70 \\
\hline Rubble & 0.18 & 0.01 & 0.02 & 0.62 & 0 & 0 \\
\hline Gorgonian & 0.02 & 0.00 & 0 & 0.08 & 0.08 & 0.10 \\
\hline Live sponge & 0.17 & 0.12 & 0.20 & 0.16 & 0.34 & 0.20 \\
\hline
\end{tabular}



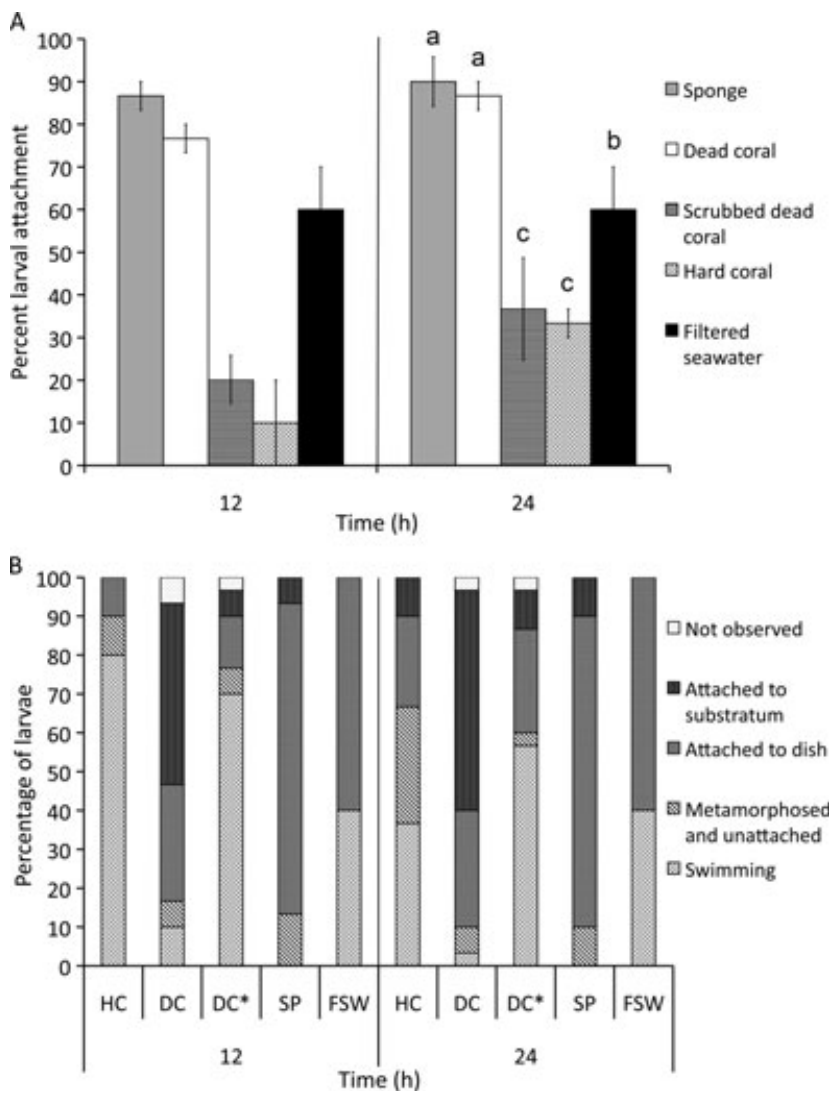

Fig. 1. Response of larvae of Mycale laevis when exposed to five substrata in petri dishes $(n=3)$. A. Mean percentage attachment at 12 and $24 \mathrm{~h}$. B. Mean percentage response at 12 and $24 \mathrm{~h}$. Ten larvae were exposed to a single piece of substratum in each petri dish. Error bars indicate standard errors, and letters above columns denote categories as indicated by the Student Newman-Keuls post hoc analysis at $24 \mathrm{~h}$. Observed larval responses were: attached to the petri dish, attached to the substratum, metamorphosed and unattached, actively swimming, or not observed. DC, dead coral; DC*, scrubbed dead coral; FSW, filtered seawater (control); HC, live scleractinian coral (Agaricia tenuifolia); SP, live sponge (Amphimedon compressa).

Am. compressa, $80.0 \pm 0.0 \%$ (no variation among replicates) of the larvae were attached to the petri dish surface while $10.0 \pm 5.8 \%$ were attached to the sponge piece at $24 \mathrm{~h}$. More larvae exposed to dead coral attached to the substratum itself, with $50.7 \pm 14.5 \%$ of the larvae settled on dead coral compared to $30.0 \pm 17.3 \%$ settled on the dish at $24 \mathrm{~h}$ (Fig. 1B). In treatments with live coral, scrubbed dead coral, and filtered seawater, $36.7-56.7 \%$ of the larvae were still swimming at $24 \mathrm{~h}$, while almost no larvae were still swimming $24 \mathrm{~h}$ after exposure to dead coral or to Am. compressa. Rates of larval metamorphosis without prior attachment to a substratum varied across treatments and time (Fig. 1B).

\section{Larval settlement in response to sponge tissues}

In a second series of settlement assays, larvae of $M$. laevis did not preferentially respond to pieces of healed sponge tissue from any sponge species, including conspecific sponges (Fig. 2). Although there was a significant time $\mathrm{X}$ substratum interaction (repeated-measures ANOVA, $\mathrm{p}=0.001$ ), the main effect of substratum was not significant $(\mathrm{p}=0.548)$. In contrast to the previous larval settlement assay, attachment at $24 \mathrm{~h}$ when larvae were exposed to Am. compressa was low, at $40.0 \pm 15.3 \%$ (Fig. 2). Proportional larval attachment did not differ between the treatments with sponge pieces and the control with filtered seawater. The treatment with dead coral had the highest proportional attachment, with $80.0 \pm 11.5 \%$ of the larvae attached by $24 \mathrm{~h}$. However, due to large variance within treatments, this result was not statistically significant (one-way ANOVA with arc-sine transformed proportions, $\mathrm{p}=0.102$ ). As in the first assay with reef substrata, more attached larvae settled on the substratum instead of the dish in the treatment with dead coral $(72.5 \pm 18.45 \%$ of attached larvae), compared with larvae exposed to Am. compressa $(20.6 \pm 10.4 \%)$. The percentages of attached larvae that settled on Aplysina cauliformis, Iotrochota birotulata, and $M$. laevis instead of on the petri dish were $22.2 \pm 22.2 \%$, $36.1 \pm 7.3 \%$, and $52.8 \pm 12.1 \%$, respectively.

When larvae were exposed to varying concentrations of sponge juice from Am. compressa, metamorphosis and attachment occurred earliest in the wells containing juice at higher concentrations. In filtered seawater and the $1 / 100 \times$ and $1 / 1000 \times$ sponge juice concentrations, $73.3-100 \%$ of larvae were still swimming at $6 \mathrm{~h}$, but all the individuals in the $1 \times$ and $1 / 10 \times$ treatments were either attached, metamorphosed, or both. Larvae in the $1 \times$ treatment responded almost immediately to the sponge juice, and attached within a few minutes of exposure, remaining attached until they all died by $48 \mathrm{~h}$. More than half of the attached larvae in the $1 / 10 \times$ treatment detached at $12 \mathrm{~h}$, with most of them re-attaching by $24 \mathrm{~h}$. Metamorphosis without attachment was not common across all treatments, and not observed in filtered seawater. Proportional attachment (including larvae that were attached and metamorphosed) at $24 \mathrm{~h}$ was statistically different across sponge juice concentrations (Kruskal-Wallis, $\mathrm{p}=0.012$ ). There was more larval attachment in the high concentration treatments of $1 \times$ and $1 / 10 \times$ $(100 \pm 0 \%$ and $93.3 \pm 7.8 \%$, respectively) at $24 \mathrm{~h}$ compared with the other treatments, which ranged from no attachment in filtered seawater to $6.7 \pm 6.7 \%$ 


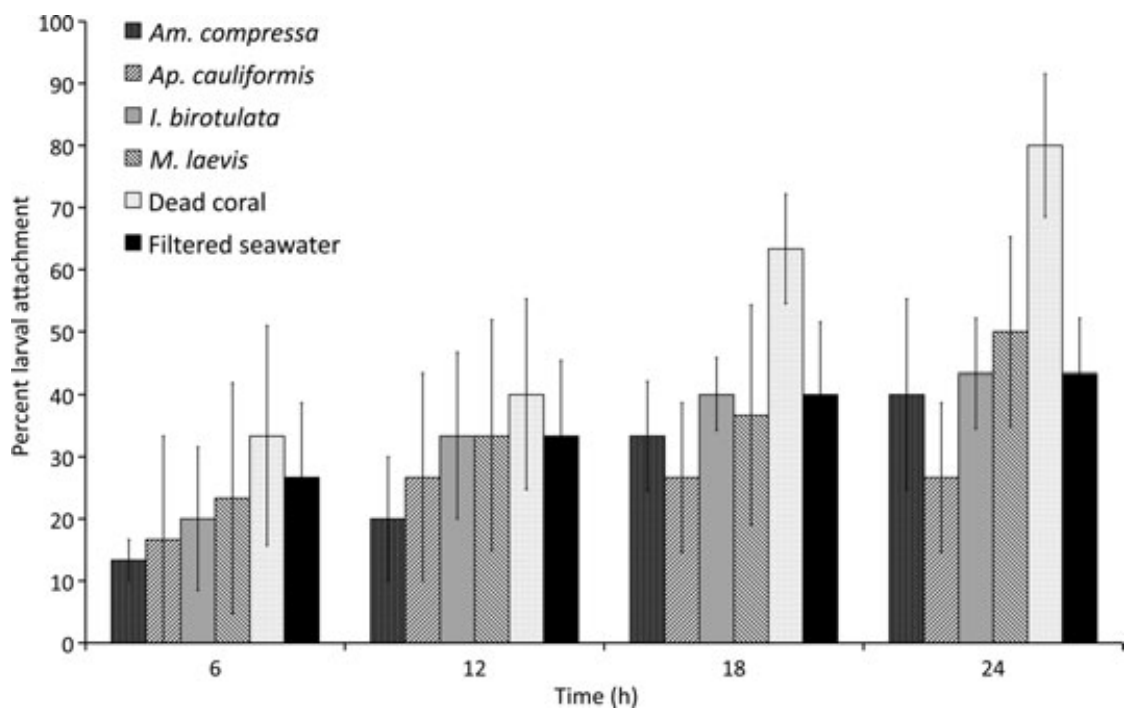

Fig. 2. Mean percentage attachment of the larvae of Mycale laevis when exposed to healed pieces of reef sponges in petri dishes over $24 \mathrm{~h}(n=3)$. Ten larvae were exposed to single sponge piece for each replicate. Error bars indicate standard errors. Filtered seawater was the control, and dead coral was used as an alternative substratum.

in $1 / 1000 \times$ and $20.0 \pm 0 \%$ in $1 / 100 \times$ sponge juice. At $72 \mathrm{~h}$, attachment remained high in the $1 / 10 \times$ treatment, but was not significantly different across juice concentrations $(\mathrm{p}=0.093)$. The $1 \times$ treatment was not included in the analysis of attachment at $72 \mathrm{~h}$, as all the larvae were dead by $48 \mathrm{~h}$. The post-metamorphic "flattened" stage was first observed in $1 / 100 \times$ and $1 / 1000 \times$ sponge juice and in filtered seawater at $12 \mathrm{~h}$, and the total number of flattened stage juveniles increased over time (Fig. 3). Most of the individuals in the $1 / 1000 \times$ treatment $(86.7 \pm 13.3 \%)$, and about half of the individuals in filtered seawater and the $1 / 100 \times$ treatment $(53.3 \pm 6.7 \%$ and $40.0 \pm 23.1 \%$, respectively) reached the flattened stage by $72 \mathrm{~h}$ (Fig. 3). None of the larvae exposed to the $1 \times$ and $1 / 10 \times$ concentrations of sponge juice developed to the flattened stage over $72 \mathrm{~h}$. Larval mortality was only observed in the $1 \times$ treatment.

When exposed to $2 \times$ concentrations of sponge juice, $73.3 \pm 17.6 \%$ of the larvae of $M$. laevis metamorphosed without attachment by $6 \mathrm{~h}$ post-exposure, compared to $13.3 \pm 13.3 \%$ in filtered seawater, although the difference was not significant $(\mathrm{p}=0.072)$. However, larvae in the $2 \times$ treatment also experienced high mortality, with all the larvae dead by $30 \mathrm{~h}$, while individuals in filtered seawater continued to attach and develop over $48 \mathrm{~h}$.

\section{Larval release and morphology}

Larvae inside brooding specimens of $M$. laevis were packed into irregularly shaped larval chambers with a mean diameter of $5.12 \pm 0.64$ (SE) $\mathrm{mm}(n=12$

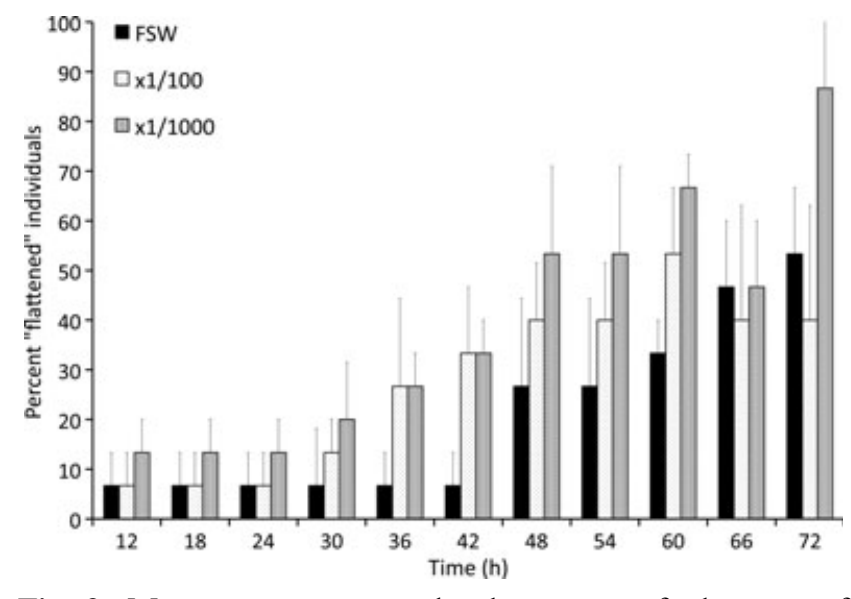

Fig. 3. Mean percentage development of larvae of M. laevis to the "flattened" stage over $72 \mathrm{~h}$ when exposed to varying concentrations of juice from Am. compressa. The first flattened individuals were observed at $12 \mathrm{~h}$. Five larvae were exposed to $10 \mathrm{~mL}$ of sponge juice in a culture plate well $(n=3)$. Error bars indicate standard errors. No individuals exposed to $1 \times$ and $1 / 10 \times$ juice concentrations developed to the flattened stage. FSW, filtered seawater (control).

individuals) that were shallowly dispersed in the choanosome. Larval chambers were typically located $5.18 \pm 0.46 \mathrm{~mm}(n=12)$ from the outer surface of the sponge. Brooded larvae ranged from white to pale green, and were green when released, with a mean length of $728.00 \pm 24.45 \mu \mathrm{m}$ and a mean width of $573.50 \pm 15.51 \mu \mathrm{m}(n=20)$. The anterior pole of the larva was characterized by a yellow disk, and a ring of cilia was found around the posterior pole. 
Individuals of $M$. laevis in aquaria did not show signs of stress, as oscules were fully open and pumping, and no discoloration of sponge tissues was observed. Sponges released larvae in small quantities throughout both daytime and nighttime, with no clear maximal release period noted over $4 \mathrm{~d}$. Mean number of larvae released at the following 8-h time periods were: $9.50 \pm 2.33$ (SE) larvae from 0600 to 1400 ( $n=4$ time periods), $6.00 \pm 2.65$ larvae from 1400 to $2200(n=3)$, and $2.67 \pm 2.19$ larvae from 2200 to $0600(n=3)$. An additional observation from the larval settlement assays was that larvae were able to fuse with one another at any stage of the settlement process. Fusion did not appear to affect survivorship or further development.

\section{Discussion}

Larval settlement in sponges is generally viewed as non-specific (Maldonado 2006), conforming to the results of our settlement assays, in which larvae of Mycale laevis were observed to settle on a variety of substrata. Although there was a trend of enhanced settlement on dead coral, the results were not consistent when assays were repeated. In the field, individuals of $M$. laevis can be found growing on several types of surfaces, from the undersides of live coral colonies to mangrove roots and other sponge species. Settlement is not limited to stable reef structures; on the calm, shallow reefs off Bocas del Toro, Panama, $M$. laevis was found growing directly on sand. Contrary to the mutualism hypothesis, larvae of $M$. laevis showed no affinity for live scleractinian coral, and responded most strongly to biofilmed dead coral. But despite the results of our settlement assays, at three of the four survey sites, more individuals of $M$. laevis were found in association with scleractinian corals than expected from the coral cover present on the reefs. The greater relative distribution of $M$. laevis on scleractinian coral is likely the result of predation on $M$. laevis, as the sponge gains a predation refuge when it grows among the branches and plates of scleractinian corals. Live coral colonies are also more structurally complex than dead corals, which, like coral pavement, are often eroded. We conclude that the distribution of $M$. laevis on reefs can be best explained by post-settlement mortality, with recruits exposed to predators more likely to be eaten. The reefs off Punta Caracol, Panama, are heavily overfished and have much lower densities of spongivorous fish compared with reefs off Key Largo (Loh \& Pawlik 2009). As such, members of $M$. laevis at Punta Caracol are subject to less predation pressure than sponges on reefs off Key Largo, and the adult distribution reflects the non-specific larval settlement patterns more closely. Adriana's Reef, Panama, like Punta Caracol, is also overfished, but the spongivorous seastar Oreaster reticulatus is abundant on this reef (Loh \& Pawlik 2009), which drives a sponge distribution pattern more similar to that seen in Key Largo.

The propensity for sponge larvae to preferentially settle on coral rubble in still water has been reported in other species (Abdul Wahab et al. 2011). However, when we repeated settlement assays with seasoned pieces of dead coral, proportional larval attachment was not significantly different from those on other reef substrata. The larvae may be responding to the biofilm on the surfaces of the dead coral rather than to the coral skeleton itself. Again, sponge larval responses to biofilm have been previously described, with faster metamorphosis recorded for larvae of Aplysilla sp. in the presence of surface biofilms (Woollacott \& Hadfield 1996). However, it should be noted that post-metamorphic survival and development in Aplysilla sp. were not subsequently monitored.

Settlement of larvae of $M$. laevis in response to pieces of the chemically defended sponge Amphimedon compressa was probably an artifact of the experimental procedure rather than a specific response that evolved as part of a sponge-sponge associational defense. In the first series of settlement assays, larvae were exposed to freshly cut pieces of $\mathrm{Am}$. compressa in small volumes of still water. The sponge pieces likely produced tissue exudates from their cut surfaces, creating artificially high concentrations of bioactive metabolites. Larvae can undergo abnormal metamorphosis when exposed to bioactive compounds, which is indicative of stress, or the action of compounds on the sensory systems of the perfused larvae (Pawlik 1990). The high rates of metamorphosis and attachment of larvae of $M$. laevis when exposed to serial dilutions of the juice of Am. compressa may be a response to the amphitoxins found in members of that species (Albrizio et al. 1995), although assays with purified metabolites were not performed. Larvae exposed to both freshly cut and healed pieces of Am. compressa attached mostly to the petri dish, and not onto the sponge itself. Furthermore, metamorphosis without attachment was only observed in the treatments with sponge juice and did not occur in filtered seawater. At high concentrations of sponge juice, larvae never developed to the flattened stage after metamorphosis and experienced $100 \%$ mortality after $30-48 \mathrm{~h}$ of exposure. In similar experiments, $100 \%$ of larvae of Xestospongia bocatorensis DÍAz, THACKer, RÜTZLER 
\& Piantoni 2007 died within a few minutes of exposure to freshly cut pieces of Am. compressa (J. Vicente, unpubl. data).

Still water assays remain popular for studying invertebrate larval behavior because they are simple to execute, and data collection is rapid and replicable. However, our assays with the juice and freshly cut pieces of Am. compressa demonstrate that positive responses to putative settlement cues can very easily be an artifact of exposure of larvae to high concentrations of bioactive metabolites (Pawlik 1990). Any apparent selective larval responses from still water assays need to be further tested to place results within a sound ecological context. Rates of metamorphosis and attachment alone are not indicative of positive larval settlement choices, and postmetamorphic monitoring or the use of flume experiments are required for a better understanding of larval responses in the field (Pawlik et al. 1991; Pawlik 1992).

From the general patterns observed in the larval settlement experiments and the adult distribution of $M$. laevis, it is clear that members of $M$. laevis do not specifically associate with scleractinian corals. As for being a facultative mutualism (Goreau \& Hartman 1966), the sponge receives obvious advantages from growing in association with coral colonies, but reciprocal benefits to the coral host, if they exist, remain to be determined (Loh \& Pawlik, in press). Although the costs and benefits of the association were not explicitly tested here, we have already determined that the sponge, which is readily consumed by sponge-eating fishes, benefits most from the refuge provided by coral plates and branches when spongivore density is high (Loh \& Pawlik 2009), and the nature of the sponge-coral association is likely to be conditional as spongivore density varies. Scleractinian corals are purportedly defended from invasion by boring sponges when associated with M. laevis (Goreau \& Hartman 1996), but this benefit is likely negated when the sponge overgrows its coral host. In areas where spongivores are removed by fishing, $M$. laevis has a fleshy, erect growth form that overgrows corals and is detrimental to their survival (Loh \& Pawlik, in press). On reefs where sponge predators are abundant, spongivorous fish graze down $M$. laevis and limit sponge overgrowth of corals (Loh \& Pawlik 2009). Only within the latter context is the association between sponge and corals possibly a facultative mutualism.

Acknowledgments. We thank the STRI Bocas station staff for facilitating research work in the laboratory and the field, and J. Vicente, Z. Jaafar, W. Leong, K. Goodman, D. Venera-Ponton, A. Castillo, and A. ChavesFonnegra for help with fieldwork. T. Henkel provided advice and aid in larval trap construction; S. McMurray, D. Hines, and three anonymous reviewers suggested improvements to the manuscript. This study was supported by grants from the AMNH Lerner Gray Fund for Marine Research, UNCW Brauer Fellowship and Graduate Student Association Travel Award, NOAA-NURC (NA96RU-0260), NOAA's Coral Reef Conservation Program and the National Science Foundation (OCE0550468, 1029515). Fieldwork in Florida was conducted under the permit FKNMS-2009-126.

\section{References}

Abdul Wahab MA, de Nys R, \& Whalan S 2011. Larval behaviour and settlement cues of a brooding coral reef sponge. Coral Reefs 30: 451-460.

Albrizio S, Ciminiello P, Fattorusso E, Magno S, \& Pawlik JR 1995. Amphitoxin, a new high molecular weight antifeedant pyridinium salt from the Caribbean sponge Amphimedon compressa. J. Nat. Prod. 58: 647-652.

Avila E \& Carballo J 2006. Habitat selection by larvae of the symbiotic sponge Haliclona caerulea (Hechtel, 1965) (Demospongiae, Haplosclerida). Symbiosis 41: 21-29.

Bergquist PR 1978. Sponges. University of California Press, Berkeley and Los Angeles, CA.

Bergquist PR \& Green C 1977. Ultrastructural study of settlement and metamorphosis in sponge larvae. Cah. Biol. Mar. 18: 289-302.

Bergquist PR \& Sinclair ME 1968. The morphology and behaviour of larvae of some intertidal sponges. New Zeal. J. Mar. Fresh. 2: 426-437.

Chesson J 1978. Measuring preference in selective predation. Ecology 59: 211-215.

Collin R, Mobley AS, Lopez LB, Leys SP, Diaz MC, \& Thacker RW 2010. Phototactic responses of larvae from the marine sponges Neopetrosia proxima and Xestospongia bocatorensis (Haplosclerida: Petrosiidae). Invert. Biol. 129: 121-128.

Crocker L \& Reiswig H 1981. Host specificity in spongeencrusting zoanthidea (Anthozoa: Zoantharia) of Barbados, West Indies. Mar. Biol. 65: 231-236.

Engel S \& Pawlik JR 2000. Allelopathic activities of sponge extracts. Mar. Ecol. Prog. Ser. 207: 273-281.

English S, Wilkinson C, \& Baker V 1997. Survey Manual for Tropical Marine Resources. Australian Institute of Marine Science, Townsville, Australia.

Goreau TF \& Hartman WD 1966. Sponge: effect on the form of reef corals. Science 151: 343-344.

Hajdu E \& Rützler K 1998. Sponges, genus Mycale (Poecilosclerida: Demospongiae: Porifera), from a Caribbean mangrove and comments on subgeneric classification. P. Biol. Soc. Wash. 111: 737-773.

Harder T, Lau SCK, Dahms H-U, \& Qian P-Y 2002. Isolation of bacterial metabolites as natural inducers for 
larval settlement in the marine polychaete Hydroides elegans (Haswell). J. Chem. Ecol. 28: 2029-2043.

Henkel TP 2008. Ecology of the obligate sponge-dwelling brittlestar Ophiothrix lineata. PhD thesis, Department of Biology and Marine Biology, University of North Carolina Wilmington, Wilmington, NC.

Heyward AJ \& Negri AP 1999. Natural inducers for coral larval metamorphosis. Coral Reefs 18: 273-279.

Hill MS 1998. Spongivory on Caribbean reefs releases corals from competition with sponges. Oecologia 117: 143-150.

Hughes T 1984. Population dynamics based on individual size rather than age: a general model with a reef coral example. Am. Nat. 123: 778-795.

Jackson D, Leys SP, Hinman VF, Woods R, Lavin MF, \& Degnan BM 2002. Ecological regulation of development: induction of marine invertebrate metamorphosis. Int. J. Dev. Biol. 46: 679-686.

Lindquist N 1996. Palatability of invertebrate larvae to corals and sea anemones. Mar. Biol. 126: 745-755.

Lindquist N \& Hay ME 1996. Palatability and chemical defense of marine invertebrate larvae. Ecol. Monogr. 66: 431-450.

Loh T-L, \& Pawlik JR 2009. Bitten down to size: fish predation determines growth form of the Caribbean coral reef sponge Mycale laevis. J. Exp. Mar. Biol. Ecol. 374: 45-50.

2012. Friend or foe? No evidence that the association with the sponge Mycale laevis provides a benefit to corals of the genus Montastraea. Mar. Ecol. Prog. Ser. in press.

Loh T-L, López-Legentil S, Song BK, \& Pawlik JR 2012. Phenotypic variability in the Caribbean Orange Icing sponge Mycale laevis (Demospongiae: Poecilosclerida). Hydrobiologia 687: 205-217.

Maldonado M 2006. The ecology of the sponge larva. Can. J. Zoolog. 84: 175-194.

Mariani S, Piscitelli MP, \& Uriz MJ 2001. Temporal and spatial co-occurrence in spawning and larval release of Cliona viridis (Porifera: Hadromerida). J. Mar. Biol. Assoc. U.K. 81: 565-567.

McMurray S, Henkel T, \& Pawlik JR 2010. Demographics of increasing populations of the giant barrel sponge Xestospongia muta in the Florida Keys. Ecology 91: 560-570.

Mokady O, Bonar D, Arazi G, \& Loya Y 1991. Coral host specificity in settlement and metamorphosis of the date mussel Lithophaga lessepsiana (Vaillant, 1865). J. Exp. Mar. Biol. Ecol. 146: 205-216.

Morse DE, Morse A, Raimondi PT, \& Hooker N 1994. Morphogen-based chemical flypaper for Agaricia humilis coral larvae. Biol. Bull. 186: 172-181.
Pawlik JR 1988. Larval settlement and metamorphosis of sabellariid polychaetes, with special reference to Phragmatopoma lapidosa, a reef-building species, and Sabellaria floridensis, a non-gregarious species. Bull. Mar. Sci. 43: 41-60.

1990. Natural and artificial induction of metamorphosis of Phragmatopoma lapidosa californica (Polychaeta: Sabellariidae), with a critical look at the effects of bioactive compounds on marine invertebrate larvae. Bull. Mar. Sci. 46: 512-536.

1992. Chemical ecology of the settlement of benthic marine invertebrates. Oceanogr. Mar. Biol. Annu. Rev. 30: 273-335.

1998. Coral reef sponges: do predatory fishes affect their distribution? Limnol. Oceanogr. 43: 13961399.

Pawlik JR \& Faulkner D 1986. Specific free fatty acids induce larval settlement and metamorphosis of the reefbuilding tube worm Phragmatopoma califomica (Fewkes). J. Exp. Mar. Biol. Ecol. 102: 301-310.

Pawlik JR, Butman CA, \& Starczak VR 1991. Hydrodynamic facilitation of gregarious settlement of a reefbuilding tube worm. Science 251: 421-424.

Pawlik JR, Chanas B, Toonen R, \& Fenical W 1995. Defenses of Caribbean sponges against predatory reef fish: I. Chemical deterrence. Mar. Ecol. Prog. Ser. 127: 183-194.

Pawlik JR, Henkel T, McMurray S, López-Legentil S, Loh T-L, \& Rohde S 2008. Patterns of sponge recruitment and growth on a shipwreck corroborate chemical defense resource trade-off. Mar. Ecol. Prog. Ser. 368: 137-143.

Ritson-Williams R, Becerro MA, \& Paul VJ 2004. Spawning of the giant barrel sponge Xestospongia muta in Belize. Coral Reefs 24: 160.

Ritson-Williams R, Paul VJ, Arnold SN, \& Steneck RS 2009. Larval settlement preferences and post-settlement survival of the threatened Caribbean corals Acropora palmata and A. cervicornis. Coral Reefs 29: 71-81.

Webster NS, Smith LD, Heyward AJ, Watts JEM, Webb RI, Blackall LL, \& Negri AP 2004. Metamorphosis of a scleractinian coral in response to microbial biofilms. Appl. Environ. Microb. 70: 1213-1221.

Wilcox T, Hill M, \& DeMeo K 2002. Observations on a new two-sponge symbiosis from the Florida Keys. Coral Reefs 21: 198-204.

Woollacott RM, \& Hadfield MG 1996. Induction of metamorphosis in larvae of a sponge. Invertebr. Biol. 115: 257-262. 